significant difference (.01 level) between events when the lactate values were treated by ANOVA (Table 3). ANOVA revealed a no-difference effect $(.01$ level of significance) between event-resting lactate values.

\section{THE EFFECTS OF PLYOMETRIC TRAINING ON THE VERTICAL JUMP PERFORMANCE OF ADULT FEMALE SUBJECTS}

B. P. Miller

Bedford College of Higher Education

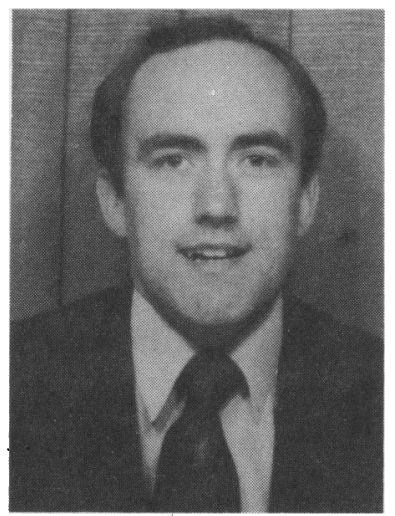

B. Miller

The aim of this study was to investigate the contention that a programme of plyometric exercises would improve the vertical jump performance of adult females.

Twenty-four female physical education students acted as subjects (Ss) and performed a standardised vertical jump test prior to being assigned to one of two groups. The mean vertical jump score was the same for each group. Group I trained with plyometric exercises and Group II acted as a control.

Ss in the plyometric training group trained once a week for eight weeks. They performed five sets of 10 repetitions of depth jumps from a height of $50 \mathrm{cms}$. All Ss were re-tested at the end of the eight week period. Results showed that Group I had improved their vertical jump performance by more than $5 \mathrm{cms}(t=2.89, d f=22$, $p<0.01$ ), whilst Group II showed no significant change.

In view of the results obtained in this study, it was suggested that sportswomen should consider the possible benefits of including depth jumping in a balanced conditioning programme. While Sinclair (1981) has emphasised that an adequate build-up of strength is required prior to undertaking such a regime, and Miller and Power (1981) have stated that depth jumps should be performed on to a gymnastic mat, it is concluded that a gradual introduction to the activity is unlikely to cause injuries.

\section{References}

Miller, B. P. and Power, S. L. D., 1981 "Developing power in athletes through the process of depth jumping". Athletics Coach 15 (2): 10-15.

Sinclair, A., 1981 "A reaction to depth jumping". Sports Coach 5 (2): 24-25.

\section{ECHOCARDIOGRAPHIC LEFT VENTRICULAR DIMENSIONS IN TWO GROUPS OF ROAD RACE CYCLISTS DURING A TRAINING SEASON \\ L. Fananapazir*, B. Ryan-Woolley*, C. Ward* and J. A. White** \\ "Regional Cardiac Centre, Wythenshawe Hospital, Manchester M23 9LT \\ * *Human Performance Laboratory, Salford University, Salford M5 4WT}

Left ventricular dimensions were measured echocardiographically, in a group of 19 competitive cyclists and in a group of 19 untrained subjects matched for age and sex. The cyclists were divided into two age groups:

Group $1-<20$ years: mean, 18 years, (range 17 to 19 years), $n=10$ and

Group $2->20$ years: mean, 26 years, (range 22 to 36 years), $n=9$.

The two groups followed similar training programmes but the older group had had perforce a longer experience of cycling. Measurements were made at the beginning and end of the competitive season.

The pre-training left ventricular dimensions were significantly greater ( $p<0.02)$ in both groups of athletes compared with the controls (Table).

\begin{tabular}{|c|c|c|c|c|c|c|}
\hline \multirow{3}{*}{$\begin{array}{l}\text { Group } 1 \\
n=10\end{array}$} & \multirow[b]{2}{*}{$\begin{array}{l}\text { Pre- } \\
\text { training }\end{array}$} & \multirow{2}{*}{$\begin{array}{l}\text { LVIDd } \\
5.2 \\
\pm 0.4\end{array}$} & \multirow{2}{*}{$\begin{array}{l}\text { LVIDs } \\
3.4 \\
\pm 0.4\end{array}$} & \multirow{2}{*}{$\begin{array}{c}\text { LVWT } \\
0.8 \\
\pm 0.1\end{array}$} & \multicolumn{2}{|c|}{$\begin{array}{r}\Delta L V \text { mass } \\
L V \text { mass } \Delta L V \text { vol }\end{array}$} \\
\hline & & & & & $\begin{array}{r}180 \\
\pm 39\end{array}$ & 4.6 \\
\hline & $\begin{array}{l}\text { Post- } \\
\text { training }\end{array}$ & $\begin{array}{r}5.5 \\
\pm 0.5\end{array}$ & $\begin{array}{r}3.5 \\
\pm 0.5\end{array}$ & $\begin{array}{r}1.3 \\
\pm 0.1\end{array}$ & $\begin{array}{r}360 \\
\pm 56\end{array}$ & \\
\hline \multirow[t]{2}{*}{$\begin{array}{l}\text { Group } 2 \\
n=9\end{array}$} & $\begin{array}{l}\text { Pre- } \\
\text { training }\end{array}$ & $\begin{array}{r}5.5 \\
+0.7\end{array}$ & $\begin{array}{r}3.4 \\
\pm 0.1\end{array}$ & $\begin{array}{r}1.0 \\
+0.2\end{array}$ & $\begin{array}{r}260 \\
\pm 92\end{array}$ & 3.5 \\
\hline & $\begin{array}{l}\text { Post- } \\
\text { training }\end{array}$ & $\begin{array}{r}5.6 \\
\pm 0.4\end{array}$ & $\begin{array}{r}3.6 \\
\pm 0.4\end{array}$ & $\begin{array}{r}1.3 \\
+0.2\end{array}$ & $\begin{array}{r}380 \\
\pm 79\end{array}$ & \\
\hline $\begin{array}{l}\text { Con trols } \\
n=19\end{array}$ & & $\begin{array}{r}4.7 \\
+0.5\end{array}$ & $\begin{array}{r}3.2 \\
\pm 0.4\end{array}$ & $\begin{array}{r}0.8 \\
\pm 0.2\end{array}$ & $\begin{array}{r}150 \\
\pm 61\end{array}$ & \\
\hline
\end{tabular}

LVID = Left ventricular internal diameter

LVWT $=$ Left ventricular posterior wall thickness

Left ventricular changes result from this type of athletic training were reflected largely in an increase in left ventricular mass rather than left ventricular volumes. On average the athletes increased their left ventricular 